\title{
STABILIZATION AND CONSOLIDATION OF HISTORICAL MULTI-LEAF MASONRY
}

\author{
JIŘÍI WITZANY ${ }^{1}$, JIŘÍ BROŽOVSKÝ ${ }^{2}$, TOMÁŠ ČEJKA ${ }^{1}$, \\ JAN KUBÁT ${ }^{1}$ AND RADEK ZIGLER ${ }^{1 *}$ \\ ${ }^{1}$ Faculty of Civil Engineering (FCE) \\ Czech Technical University in Prague (CTU in Prague) \\ Thákurova 7, 16629 Prague, Czech Republic \\ e-mail: \{witzany, cejka, jan.kubat.2, zigler\}@fsv.cvut.cz, kps.fsv.cvut.cz $\left({ }^{*}\right.$ corresponding author $)$ \\ ${ }^{2}$ Faculty of Civil Engineering (FAST) \\ VSB - Technical University of Ostrava (VSB-TUO) \\ Ludvíka Podéště 1875/17, 70800 Ostrava-Poruba, Czech Republic \\ email: jiri.brozovsky@vsb.cz, www.fast.vsb.cz
}

Keywords: Multi-leaf Masonry, Historical Structures, Failure Mechanism, Stabilization

\begin{abstract}
Historical masonry structures with a greater thickness can often be made as socalled multi-leaf masonry with outer leaves lined with the application of some of the masonry bonding methods and with the inner leave of the so-called cast core formed by fragments of stones of different sizes that are bonded with more mortar. The load capacity, stiffness and the failure mechanism of multi-leaf masonry are influenced by the interaction of individual leaves with different deformation and physico-mechanical properties and the nature of the mutual connection of individual leaves of masonry. The performed analyses showed a significant influence of especially the cast core masonry tensile strength and the contact joint strength between the core masonry and the outer leaves.
\end{abstract}

\section{INTRODUCTION}

Failure mechanism of multi-leaf masonry with outer layers (facing leaves) of coursed masonry of regular (dressed) stone blocks, or of roughly coursed masonry with irregular, partially treated (roughly dressed) quarry stones and with an inner layer, the so-called cast core, consisting of fragments of stones differing in sizes and shapes, which are laid in a larger amount of mortar, is different from the failure mechanism of coursed stone masonry or roughly coursed irregular masonry $[1,2]$. The determination of the residual compressive loadability of multi-leaf masonry is a demanding task at which the calculation procedures used for single-leaf masonry cannot be fully applied.

Due to the nature of the inner leaf containing a larger amount of binder (e.g. $40-60 \%$ of the generally more flexible binder) than the outer masonry leaves (e.g., 15-30\% binder), different deformation properties, a different load capacity and failure mechanism of this type of masonry can be expected [3]. The "bonding" of the outer leaves with the inner leaf contributes to the increase in the coherence and integrity of multi-leaf masonry. Also, the natural irregularity of 
the inner surface of the outer (facing) leaves made of undressed stones improves the bonding of the outer and inner leaves and increases the resistance of the multi-leaf masonry structure to "splitting", which usually precedes complete failure of masonry.

The process of multi-leaf masonry failure under concentric compressive loads is characterized by the detachment of individual masonry leaves, damage to the masonry crosssection due to transverse (expanding) tensile forces usually caused by the different stiffness of the cast core and the facing leaf masonry $[4,5,6]$.

Historical masonry is characterized by considerable heterogeneity and different properties of its individual components $[7,8,9,10]$. The study of the influence of different material properties of individual parts of multi-leaf masonry on its failure mechanism is therefore a basic prerequisite for its reliable stabilization and consolidation design.

\section{THEORETICAL AND EXPERIMENTAL RESEARCH INTO THE BEHAVIOR OF MULTI-LEAF MASONRY UNDER COMPRESSIVE LAODING}

The research projects (NAKI DF12P01OVV037 and NAKI DG16P02M055) involved the theoretical and experimental analysis of the failure mechanism of multi-leaf masonry under concentric compressive load exerted by force or by forced deformation was performed. The theoretical and experimental analysis was carried out on a model of multi-leaf masonry (Fig. 1) with outer (facing) leaves approx. $150 \mathrm{~mm}$ thick made up of roughly dressed sandstone blocks (approx. size of 170 x 150 x $120 \mathrm{~mm}$, compressive strength approx. $40 \mathrm{MPa}$ ) and a core masonry leaf approx. $300 \mathrm{~mm}$ in (mortar compressive $1.08 \mathrm{MPa}$ in the case 0 masonry of $0.92 \mathrm{MPa}$
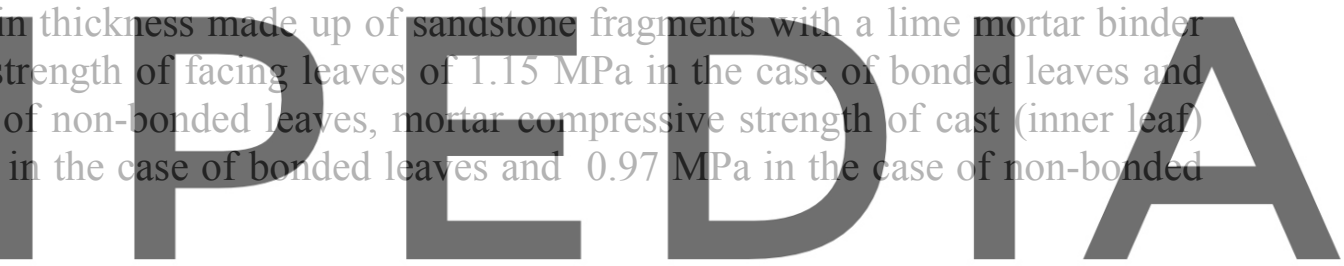
leaves).

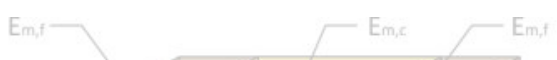

Register for free at https//www.scipedia.com to download the version without the watermark
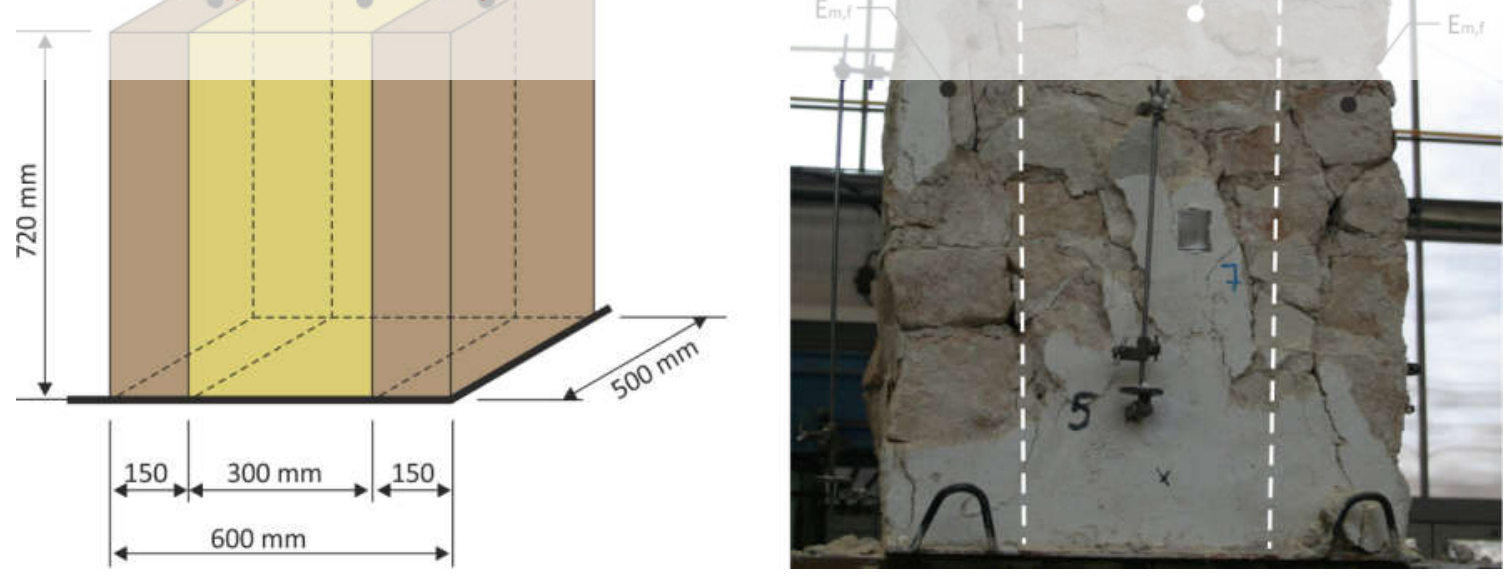

Figure 1: Multi-leaf masonry specimens

Numerical analysis (2D linear finite element analysis) included a total of 7 different arrangements of segments (bodies) of multi-leaf masonry loaded at the upper free end by a uniform vertical compressive load and 7 segments (bodies) loaded at the upper free end by 
forced vertical deformation (Fig. 2, Tab. 1). The numerical analysis covered different alternatives of computational models (single-leaf, multi-leaf, bonded and non-bonded leaves) as well as computational load models (force, forced deformation).

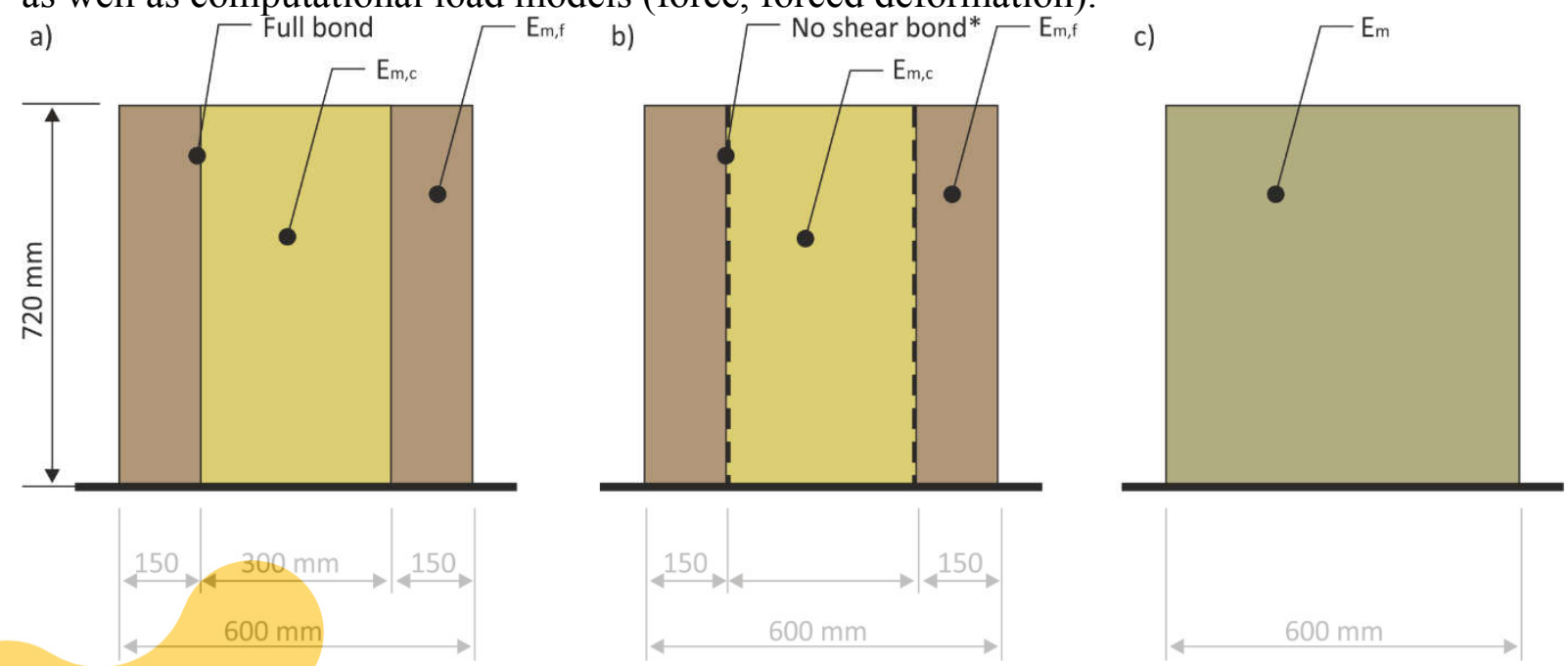

Figure 2: a) Multi-leaf masonry with full bond between leaves, b) Multi-leaf masonry with no shear bond between leaves (*horizontal stresses are transferred), c) Single-leaf masonry

Table 1: Overwiev of theoretically studied cases of multi-leaf masonry
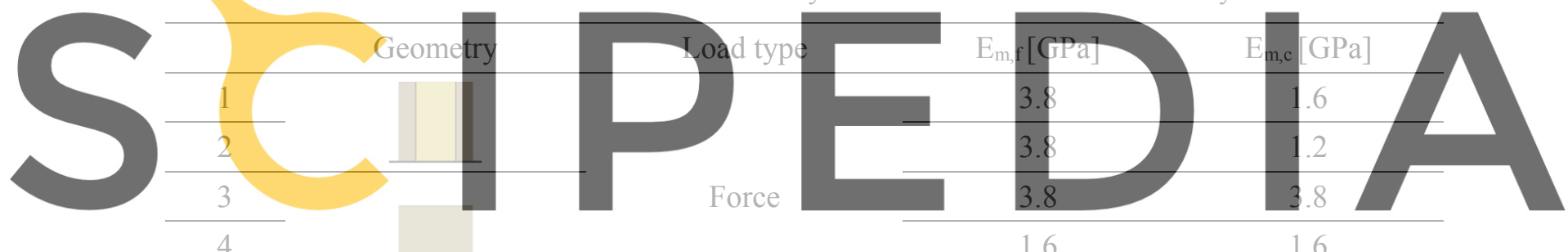

Register for fyee at https//www.scipedia.com to download the.2version without.2the watermark

\begin{tabular}{|c|c|c|c|}
\hline 6 & \multirow{5}{*}{ Deformation } & 3.8 & 1.6 \\
\hline 7 & & 3.8 & 1.2 \\
\hline 8 & & 3.8 & 3.8 \\
\hline 9 & & 1.6 & 1.6 \\
\hline 10 & & 1.2 & 1.2 \\
\hline 11 & \multirow{2}{*}{ Force } & 3.8 & 1.6 \\
\hline 12 & & 3.8 & 1.2 \\
\hline 13 & \multirow{2}{*}{ Deformation } & 3.8 & 1.6 \\
\hline 14 & & 3.8 & 1.2 \\
\hline
\end{tabular}

The experimental research was carried out on a total of 6 test specimens of the same dimensions as in the theoretical analysis (width $\mathrm{x}$ depth $\mathrm{x}$ height - approx. $500 \times 600 \times 720 \mathrm{~mm}$ ) loaded by a monotonically increasing compressive force exerted by a hydraulic press with a digital pressure sensing center (manufacturer MFL Germany, load range 0 - 10000 kN, Fig. 3). 
Based on the theoretical and experimental analysis of multi-leaf masonry segments, two different failure mechanisms of multi-leaf masonry under concentric compressive load were formulated.
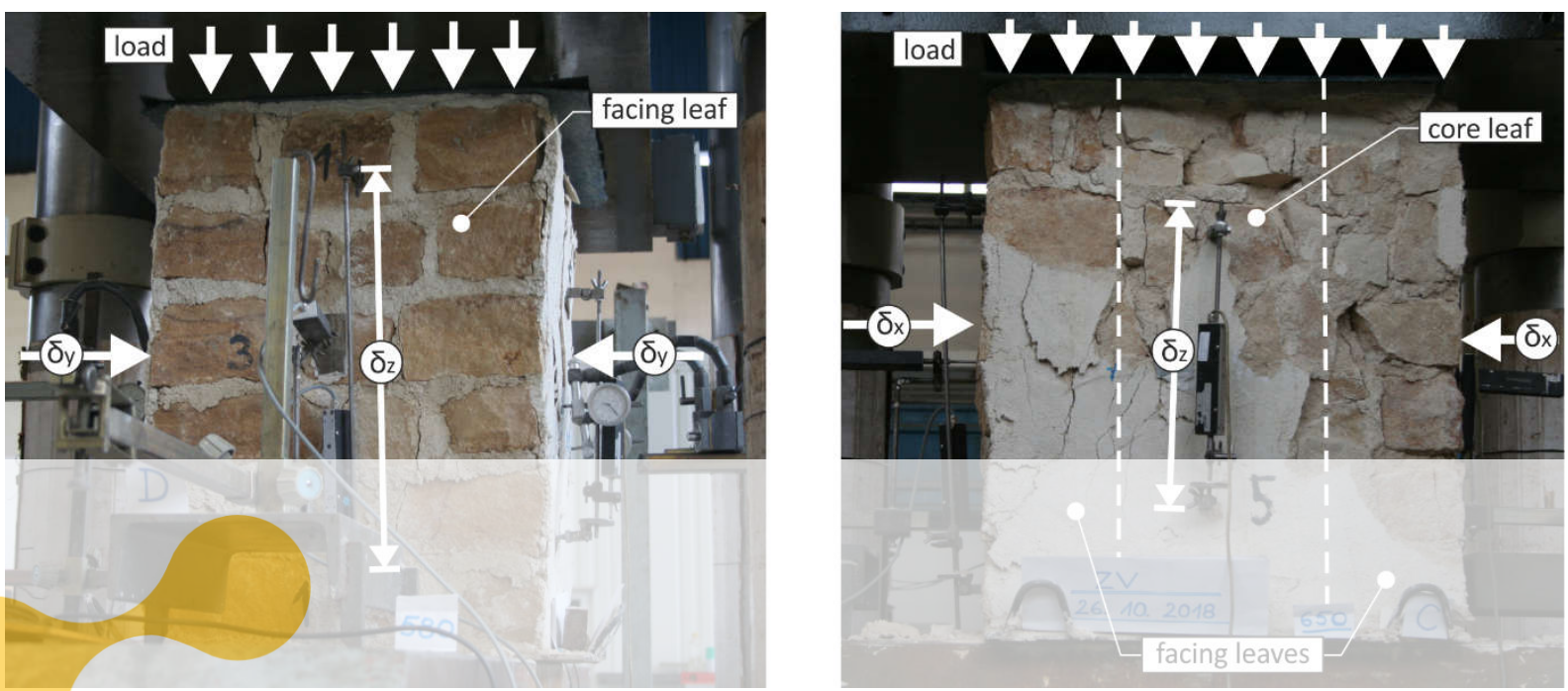

Figure 3: Test specimens of multi-leaf masonry under compressive load

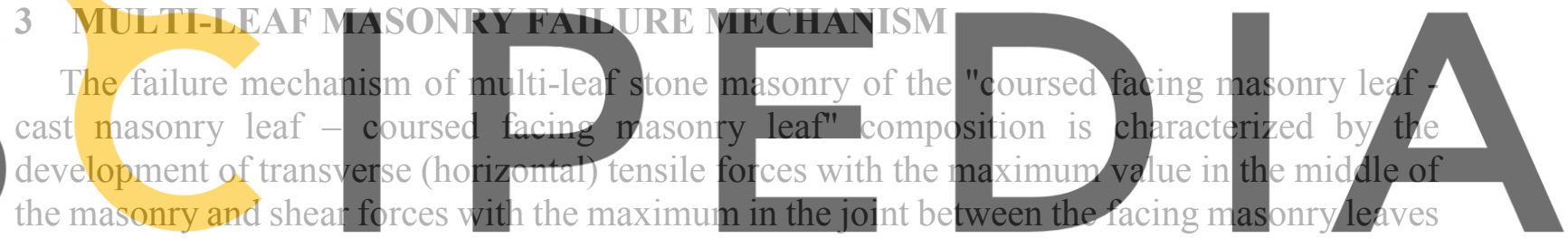
and the cast core leaf (Fig. 4).

Register for free at https//www.scipedia.com to download the version without the watermark
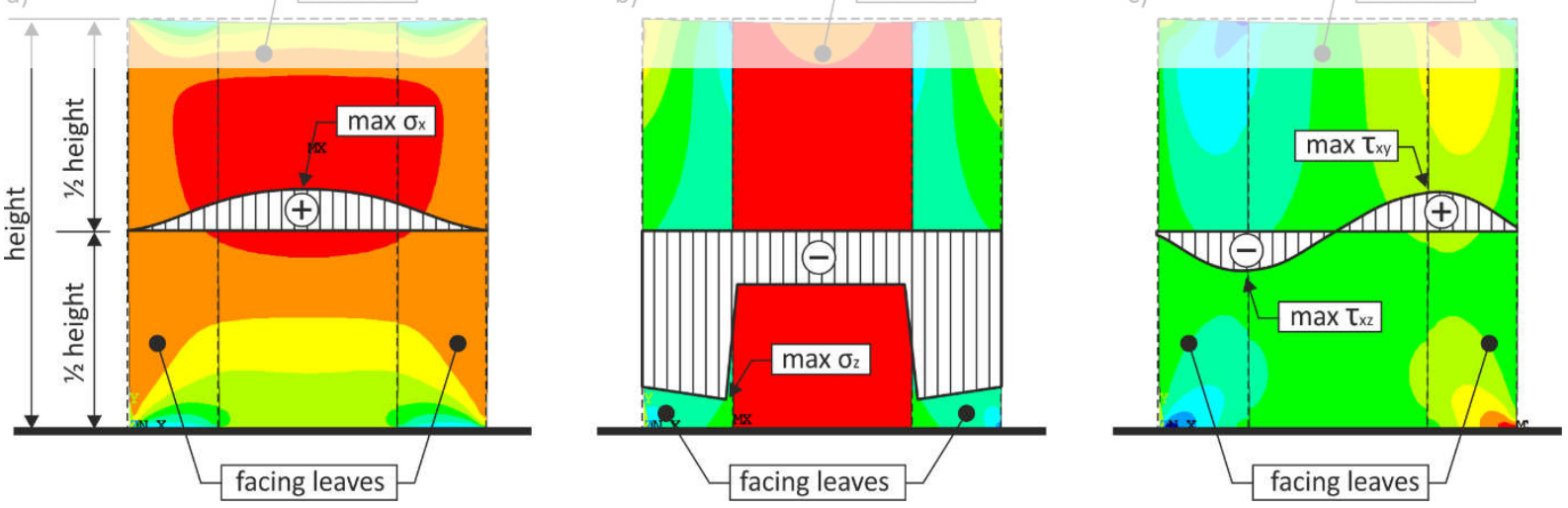

Figure 4: Results of numerical analysis - a) Horizontal stresses, b) Vertical stress, c) Shear stresses

Based on the results of the numerical analysis, deflection of stress trajectories in multi-leaf masonry loaded by concentric compression due to the higher stiffness of facing masonry leaves $\mathrm{E}_{\mathrm{m}, \mathrm{f}}$ (lower compressibility) compared to the stiffness of the core masonry leaf $\mathrm{E}_{\mathrm{m}, \mathrm{c}}$ can be observed. This deflection of the stress trajectories (change from the vertical trajectory in case 
of single-leaf masonry or masonry where $\mathrm{E}_{\mathrm{m}, \mathrm{f}} \approx \mathrm{E}_{\mathrm{m}, \mathrm{c}}$ to more complex or inclined stress pattern in case of $\mathrm{Em}, \mathrm{f} \neq \mathrm{Em}, \mathrm{c})$ is accompanied by the formation of horizontal stresses which increase in size with the increasing difference in the stiffness of the facing and core masonry leaves $\left(\mathrm{E}_{\mathrm{m}, \mathrm{f}}\right.$ $\left.>\mathrm{E}_{\mathrm{m}, \mathrm{c}}\right)$.

In the case of $E_{m, c} / E_{m, f}$ ration equal to 0.42 , the horizontal stresses $+\sigma_{x}$ reached $646 \%$ and $861 \%$ in case of facing leaf or core leaf, respectively, compared to a single leaf masonry. In the case of $\mathrm{E}_{\mathrm{m}, \mathrm{c}} / \mathrm{E}_{\mathrm{m}, \mathrm{f}}$ ration equal to 0.32 these stresses reach $769 \%$ and $1028 \%$ in case of facing leaf or core leaf, respectively, compared to a single leaf masonry (Fig. 5). These additional horizontal tensile stresses, combined with no uniform distribution of vertical stresses $+\sigma_{z}$ (Fig. 6) can lead to significant crack formation and masonry failure. This mechanism is further enhanced by the increase in shear stresses $+\tau_{\mathrm{xz}}$ reaching up to $775 \%$, depending on the $\mathrm{E}_{\mathrm{m}, \mathrm{c}} / \mathrm{E}_{\mathrm{m}, \mathrm{f}}$ ration (Fig. 7).
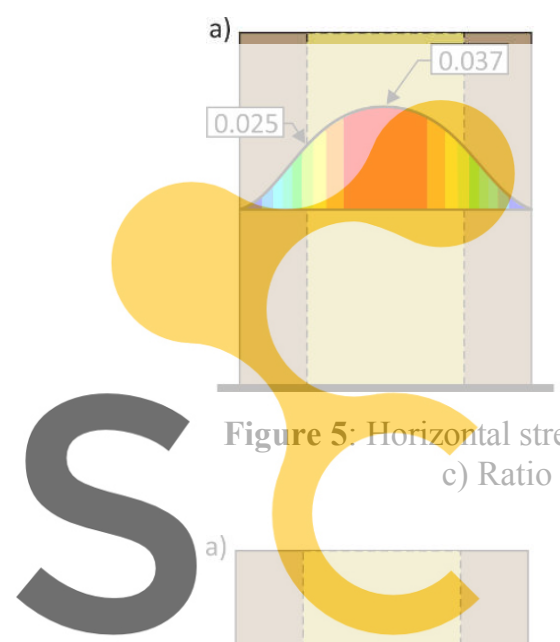

Figure 5: Horizontal stre c) Ratio
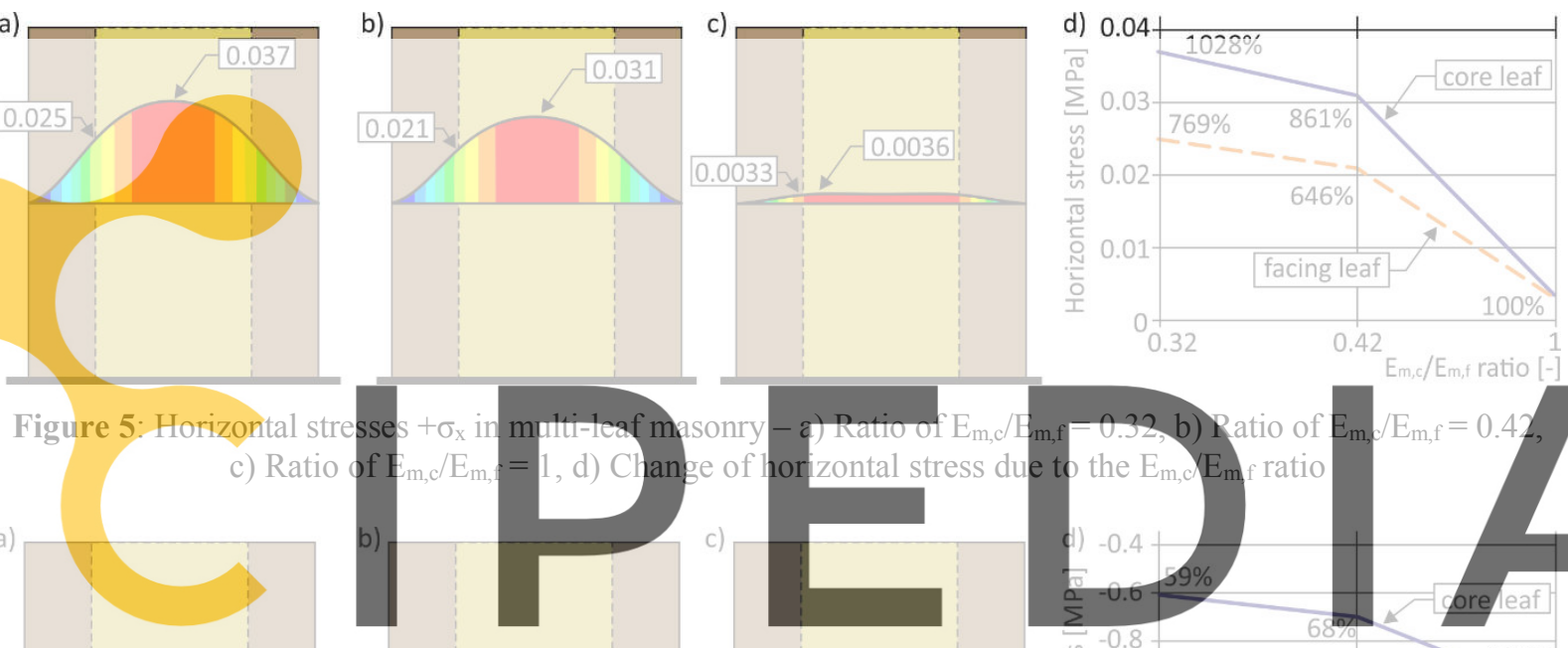

Register for free at https//www.scipedia.com
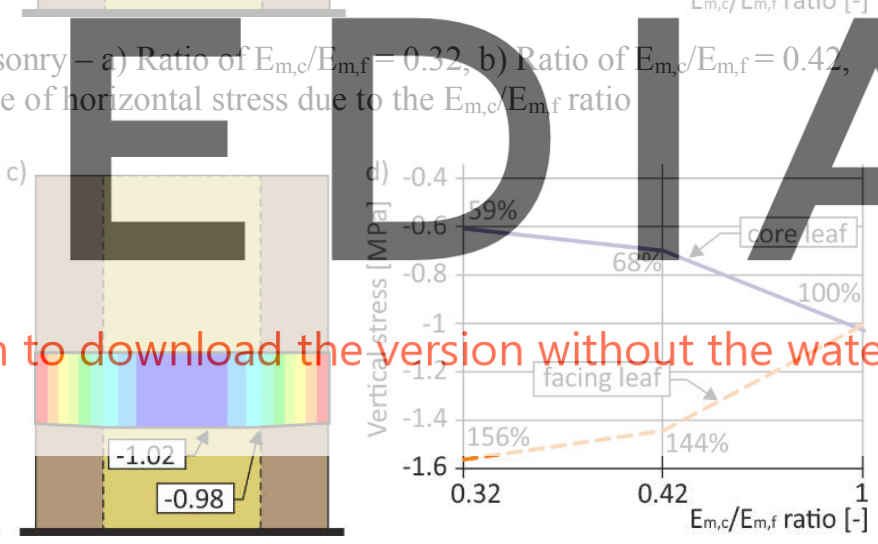

Figure 6: Vertical stresses $+\sigma_{\mathrm{z}}$ in multi-leaf masonry $\left.-\mathrm{a}\right)$ Ratio of $\mathrm{E}_{\mathrm{m}, \mathrm{c}} / \mathrm{E}_{\mathrm{m}, \mathrm{f}}=0.32$, b) Ratio of $\mathrm{E}_{\mathrm{m}, \mathrm{c}} / \mathrm{E}_{\mathrm{m}, \mathrm{f}}=0.42$, c) Ratio of $E_{m, c} / E_{m, f}=1$, d) Change of vertical stress due to the $E_{m, c} / E_{m, f}$ ratio
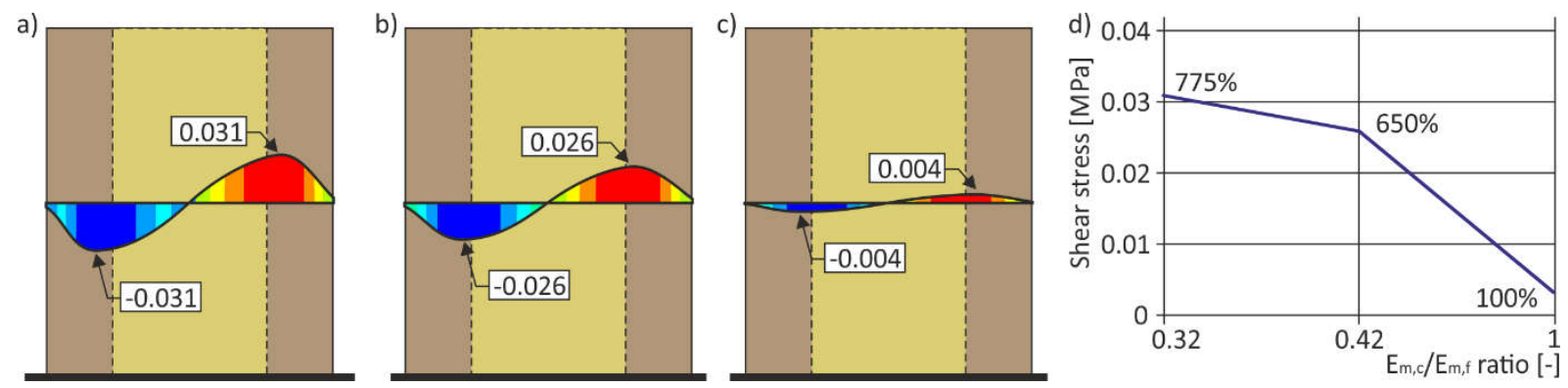

Figure 7: Shear stresses $+\tau_{\mathrm{xz}}$ in multi-leaf masonry - a) Ratio of $\mathrm{E}_{\mathrm{m}, \mathrm{c}} / \mathrm{E}_{\mathrm{m}, \mathrm{f}}=0.32, \mathrm{~b}$ ) Ratio of $\mathrm{E}_{\mathrm{m}, \mathrm{c}} / \mathrm{E}_{\mathrm{m}, \mathrm{f}}=0.42$, c) Ratio of $E_{m, c} / E_{m, f}=1$, d) Change of shear stress due to the different $E_{m, c} / E_{m, f}$ ratio 
Based on the experimental results (Fig. 8 and Fig. 9, Tab. 1 and Tab. 2), it can be stated that the characteristic failure of multi-leaf masonry depends on the tensile strength of the cast core masonry and the strength of the contact joint between the facing and the core masonry leaves.

a)
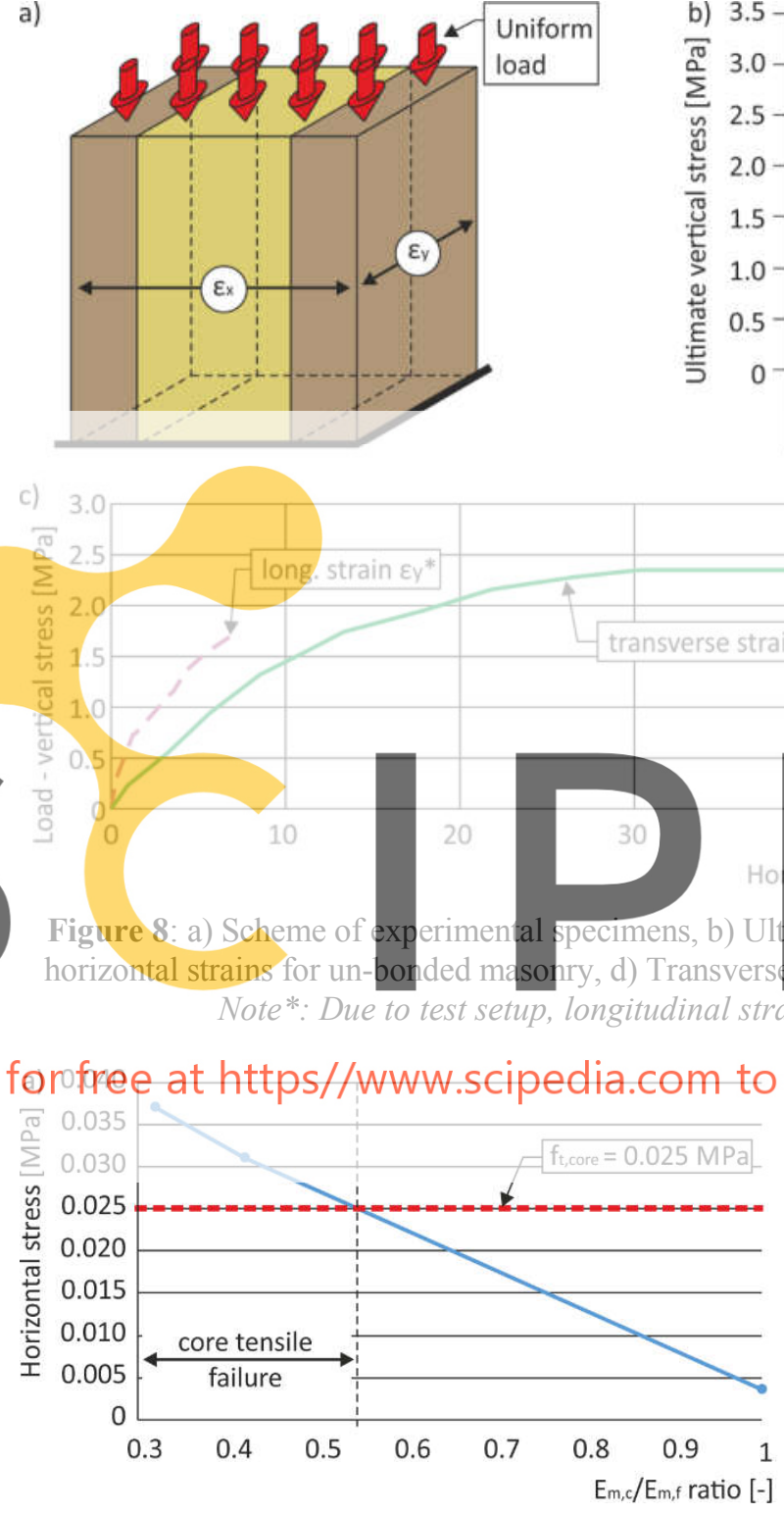

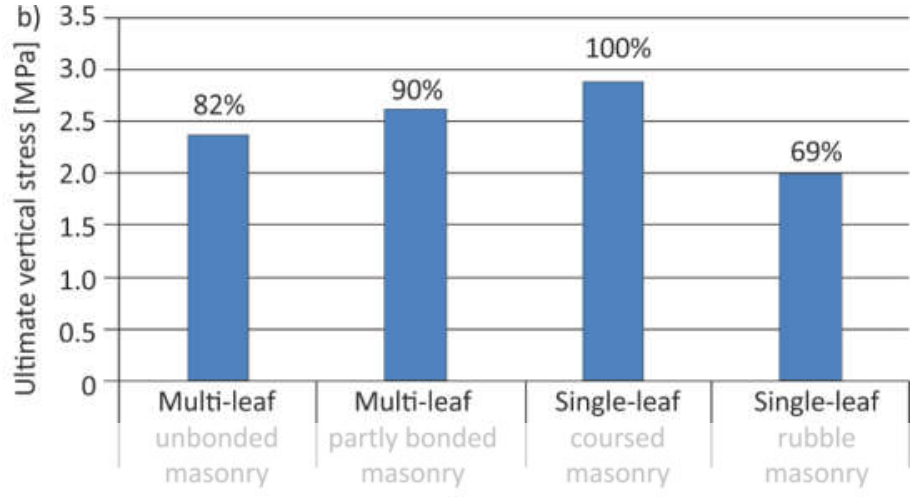

masonry
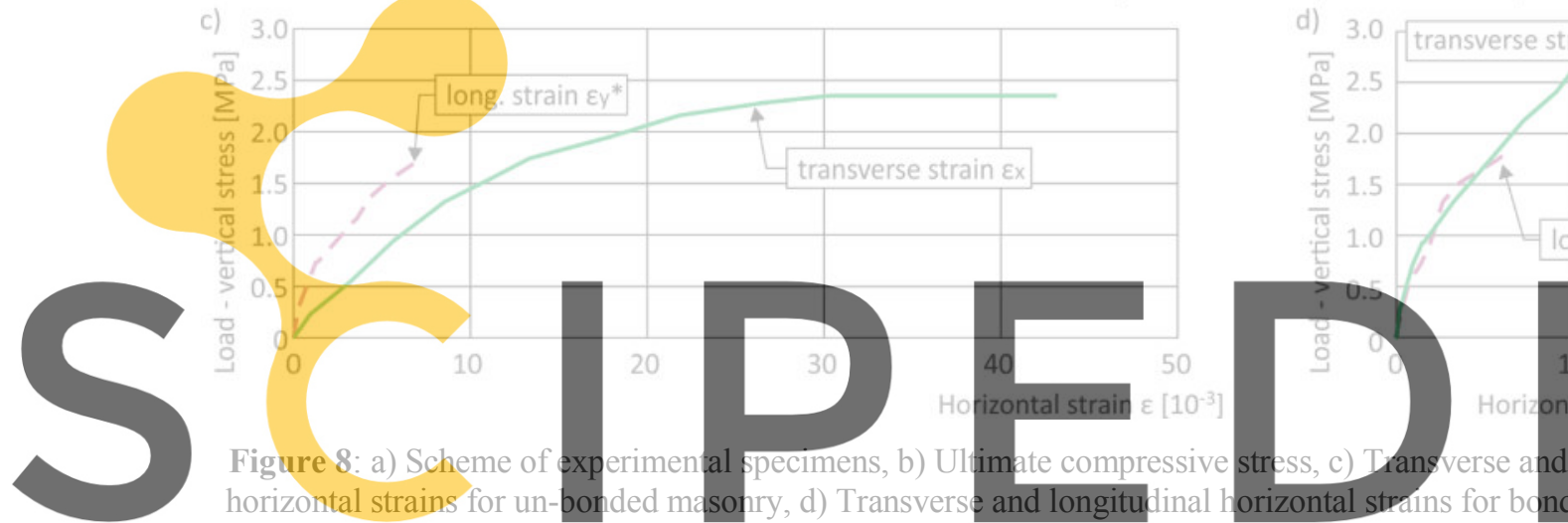

and longitudinal horizontal strains for bond

Register forofree at https//www.scipedia.com to dow.plload the version without the watermark

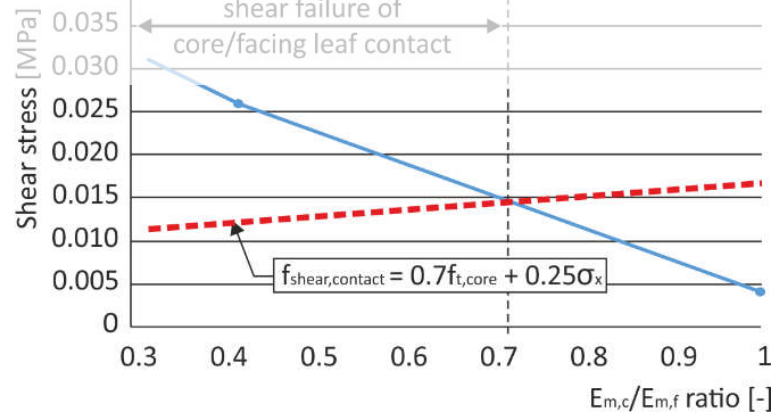

Figure 9: a) The change of tensile stresses due to the $E_{m, f} / E_{m, c}$ and tensile strength of the core leaf (rubble) masonry, b) The change of shear stresses due to the $\mathrm{E}_{\mathrm{m}, \mathrm{f}} / \mathrm{E}_{\mathrm{m}, \mathrm{c}}$ ratio and shear strength of the core/facing leaf contact

In terms of the response and the type of failure of multi-leaf masonry loaded by concentric compressive force, which precedes reaching the limit load, the loss of stability and bearing function of multi-leaf masonry, two different failure mechanisms of multilayer masonry can be distinguished: 
a) Failure mechanism of multi-leaf masonry due to reaching the ultimate strength of the core (cast) masonry. This failure mechanism of multi-leaf masonry can be observed in cases where the ultimate tensile strength of the cast core masonry is exceeded due to vertical tensile cracks, which gradually extend from the middle third of the height of the compressed masonry (walls, columns) towards the heel and head. The formation of vertical tensile cracks in the masonry core is subsequently accompanied by an uneven distribution of normal compressive stresses across the cross-section of multi-leaf masonry, which precedes reaching the limit load. The reduction of the stability - buckling strength - of the masonry parts (columns) delimited by individual vertical tensile cracks contributes to the progressiveness of the multi-leaf masonry failure mechanism.

b) Failure mechanism of multi-leaf masonry due to reaching the ultimate shear strength in the contact joint between the facing masonry leaves and the core masonry leaf. This failure mechanism of multi-leaf masonry can be observed in cases where the ultimate shear strength in the "facing leaf - core leaf - facing leaf" contact joint is exceeded and individual masonry leaves become detached. The ultimate compressive strength of multi-leaf masonry at this stage of failure depends primarily on the intensity of the uneven distribution of normal stresses and the buckling strength of the facing leaves.

Table 2: Overview of experimental multi-leaf and single-leaf masonry specimens and their material properties

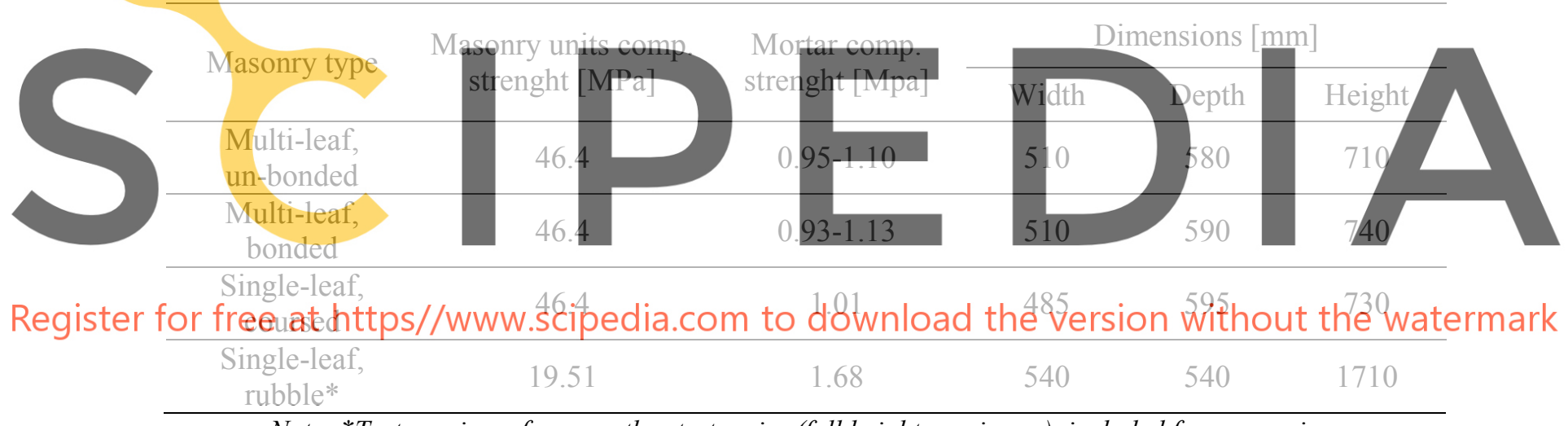

Note: *Test specimen from another test series (full height specimens), included for comparison

Table 3: Results of experimental testing of multi-leaf and single leaf masonry specimens

\begin{tabular}{ccccc}
\hline & Ultimate vert. & \multicolumn{3}{c}{ Ultimate strains $\varepsilon[-]$} \\
\cline { 3 - 5 } Masonry type & stress $\sigma_{\mathrm{z}}[\mathrm{MPa}]$ & Vertical $\left(\varepsilon_{\mathrm{z}}\right)$ & $\begin{array}{c}\text { Transverse } \\
\text { horizontal }\left(\varepsilon_{\mathrm{x}}\right)\end{array}$ & $\begin{array}{c}\text { Longitudinal } \\
\text { horizontal }\left(\varepsilon_{\mathrm{y}}\right)\end{array}$ \\
\hline $\begin{array}{c}\text { Multi-leaf, } \\
\text { un-bonded }\end{array}$ & 2.37 & 0.0117 & 0.0302 & $0.0073^{*}$ \\
\hline $\begin{array}{c}\text { Multi-leaf, } \\
\text { bonded }\end{array}$ & 2.61 & 0.0164 & 0.0143 & $0.0057^{*}$ \\
\hline $\begin{array}{c}\text { Single-leaf, } \\
\text { coursed }\end{array}$ & 2.89 & 0.0109 & 0.0169 & $\mathrm{x}$ \\
\hline $\begin{array}{c}\text { Single-leaf, } \\
\text { rubble }\end{array}$ & 1.99 & 0.0201 & 0.0342 & $\mathrm{x}$ \\
\hline \multicolumn{2}{c}{ Note: Strains at approx. $75 \%$ of ultimate load level (*), strains not measured $(x)$} \\
\end{tabular}




\section{STABILIZATION AND CONSOLIDATION OF MULTI-LEAF HISTORICAL MASONRY}

Stabilization and consolidation measures should be based on the failure mechanisms characterized by masonry splitting accompanied by reduced stability and compressive load capacity. In terms of prevention of the appearance of premature tensile cracks, which result in multi-leaf masonry splitting, the most effective methods that can be recommended, based on the research conducted and authors' experience of in-situ applications, are:

- In the case of insufficient contact joint strength or damage

- Reinforcement of multi-leaf masonry by transverse anchors (connectors) designed on the principle of the so-called "nail" grouting. After the insertion of steel bars (e.g. with periodic surfaces) into transversally drilled holes (slightly sloping inwards - approx. $5^{\circ}$, reaching to approx. $1 / 2$ of the core thickness), pressure grouting (with lime, cement or polymer based binders, resins etc.) is performed. The optimal spacing of individual grouted nail anchors (connectors), which can be arranged in one or several rows one above the other, is less than or equal to the thickness of the facing masonry leaf (Fig. 10a).

Pressure grouting aimed at reinforcing the contact joint with grouting mixtures based on polymer or epoxy resins or grouting mixtures based on lime or cement binders. The grouting hole should reach into the core leaf to a maximum depth equal to the thickness of the facing masonry leaf (Fig. 10b).
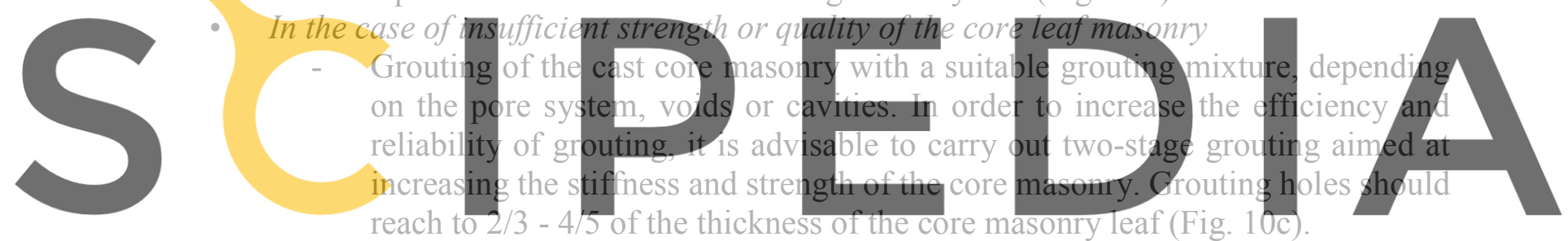

Register for free at https//www.scipedia.com to download the version without the watermark
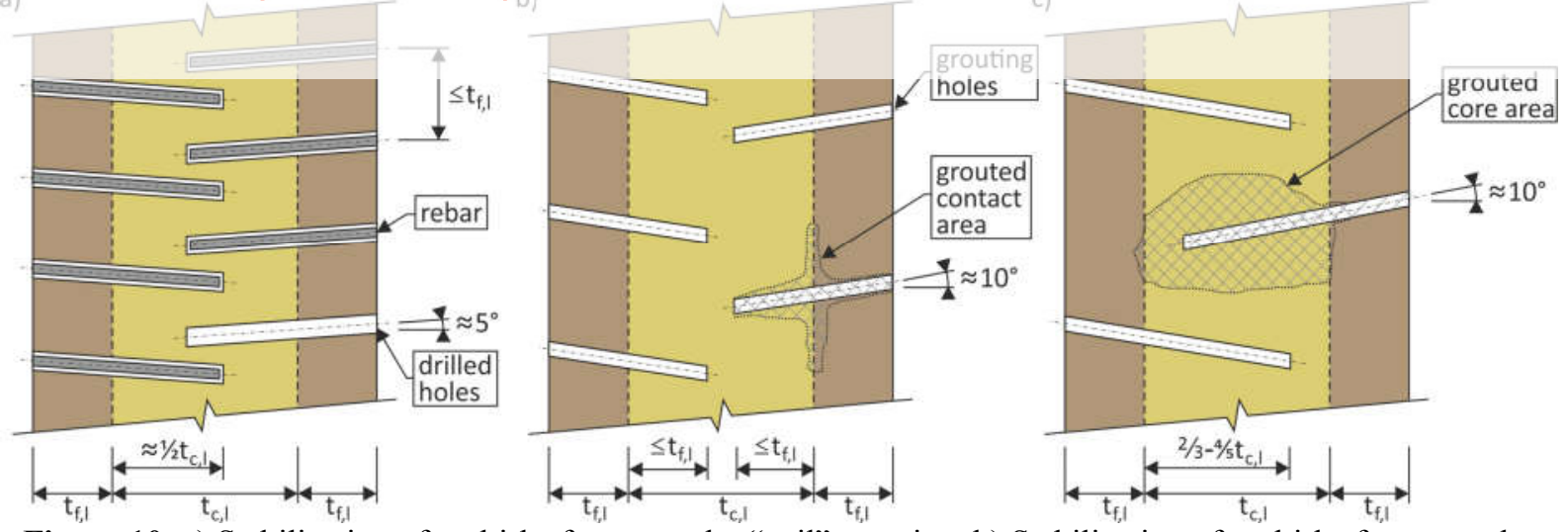

Figure 10: a) Stabilization of multi-leaf masonry by "nail" grouting, b) Stabilization of multi-leaf masonry by contact joint grouting, c) Stabilization of multi-leaf masonry by core grouting

\section{CONCLUSIONS}

The determination of the residual compressive load capacity of multi-leaf masonry and the design of remediation and reinforcement methods of damaged multi- leaf masonry requires a 
specific approach based on the results of detailed research, diagnostic investigations and theoretical analysis. Massive multi-leaf masonry usually shows sufficient reserves in the load capacity due to the magnitude of real loads. The tests and analyses performed, in contrast, pointed out the risk factors of multi-leaf masonry that may be the cause of its sudden failure (collapse).

Acknowledgements. The article was written with support from the NAKI DG16P02M055 project "Development and Research into Materials, Procedures and Technologies for Restoration, Conservation and Strengthening of Historic Masonry Structures and Surfaces and Systems of Preventive Care of Historic and Heritage Buildings Threatened by Anthropogenic and Natural Risks".

\section{REFERENCES}

[1] Stavroulaki, M., Papalou, A. Parametric analysis of old multi-leaf masonry walls International Journal of Conservation Science (2014) 5(4):435-446.

[2] Demir, C., Ilki, A., Characterization of the materials used in the multi-leaf masonry walls of monumental structures in Istanbul, Turkey. Construction and Building Materials (2014), 64:398-413.

[3] Aldreghetti, I., Baraldi, D., Boscato, G., Cecchi, A., Massaria, L., Pavlovic, M., Reccia, E.,

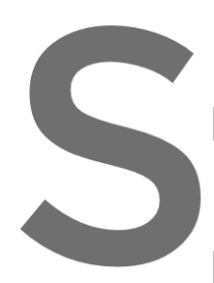
Tofani, I. Multi-leaf nasonry walls with full, damaged and consolidated infill:
Experimental and numerical anatyses. Key Engineering Moteriats (2017) 747:488-495
M. R. Valluzzi, F. da Porto, C. Modena, Behaviour of multi-leaf stone nasonry walls
strengthened by different intervention techniques, In: P.B. Lourenco, P. Roca (Eds.)
Historical Constructions (2001)
Candela, M., Bonti,A., Corradi, M., Righetti, L. Effect of transversal steel connectors on the behavior of rubble stone-masonry walls: Two case studies in Italy. Brick and Block

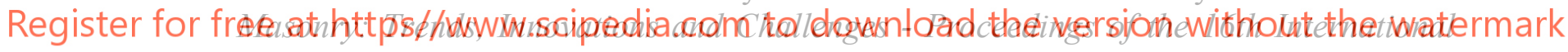
Brick and Block Masonry Conference, IBMAC 2016 (2016), pp. 2029-2038.

[6] Corradi, M., Borri, A., Poverello, E., Castori, G. The use of transverse connectors as reinforcement of multi-leaf walls. Materials and Structures/Materiaux et Constructions (2017) 50(2), art. no. 114

[7] Witzany, J., Čejka, T., Kroftová, K., Šmidtová, M., 2016. The effect of degradation processes on the serviceability of building materials of historic buildings, The Civil Engineering Journal $\mathbf{3 ( 1 0 )}$, art. no. 11

[8] Witzany, J., Zigler, R., Čejka, T., Pospíšil, P., Holický, M., Kubát, J., Maroušková, A., Kroftová, K., Physical and Mechanical Characteristics of Building Materials of Historic Buildings The Civil Engineering Journal (2017) 4(12):343-360

[9] Witzany, J., Zigler, R., Kroftová, K., Čejka, T., Kubát, J., Holický, M., Karas, J., The Effect of Pore Distribution in Historic Masonry on the Grouting Method and Grouting Mix Selection, The Civil Engineering Journal (2018) 3(10):307-329

[10]Witzany, J., Zigler, R., Čejka, T., Libecajtová, A., Polák, A., Kubát, J., 2019. Research into the effect of grouting on physical-mechanical properties of historic masonry, In: A. Zingoni (Ed.) Advances in Engineering Materials Structures and Systems: Innovations, Mechanics and Applications (2019). London: Taylor \& Francis, p. 617-618. 